\title{
Party System Nationalization, Presidential Coalitions, and Government Spending
}

\author{
Néstor Castañeda-Angarita \\ University College London
}

May 17, 2016

\begin{abstract}
This paper argues that there is a strong relationship between geographical patterns of political parties' electoral performance and the composition of central government expenditures. When party system nationalization is high, the composition of spending will focus more on non-targetable expenditures, while targetable expenditures increase as the party system distribution of votes across different districts becomes less homogeneous. However, the effect of party nationalization on spending type is conditioned by the size of the presidential coalition; targeted transfers will increase if the coalition size decreases, even if party nationalization is high. I find support for these hypotheses with an empirical analysis of district-level electoral and government expenditure data for several countries in Latin America between 1990 and 2006.
\end{abstract}

Keywords: Party Nationalization, Fiscal Policy, Federalism

Scholars in comparative political economy argue that the geographical features of the electoral system influence policy outcomes. They have shown that electoral incentives shape legislators' trade-offs between allegiance to a social constituency and allegiance to a geographic constituency. Political economy literature is full of examples showing that the nature of electoral institutions determines how fiscal resources are allocated among different constituencies (Austen-Smith 1988; Lizzeri and Persico 2001; Milesi-Ferretti, Perotti, and Rostagno 2002). For example, Persson and Tabellini (2002) show evidence that proportional-representation (PR) electoral systems are more prone to national, non-targeted spending, while majoritarian electoral systems are more geared to spend on local, targeted transfers. Similarly, other scholars show that the nature of the politicians' constituencies and electoral rules shape 
government's incentives to provide public goods and what kind of public goods they provide.

This article investigates the effect of party-system nationalization on the fiscal policy outcomes in presidential regimes with proportional-representation or mixedmember electoral systems. In line with literature on the relationship between electoral rules (outcomes) and policymaking, I contend that the objective features of the party system and the geographical patterns of parties' electoral performance -party system nationalization- affect the type of government spending in presidential regimes. In particular, I show that the central government will spend more resources on nontargeted, nationally-oriented budget allocations when party system nationalization increases, especially if the president's coalition in congress is not too small. On the other hand, the amount of transfers from central to subnational governments increases with lower levels of party system nationalization and smaller presidential coalitions. Based on the evidence presented in this article, one can argue that the geographical and distributional incentives for political competition affect fiscal policy outcomes in presidential regimes.

The structure of public finance in presidential regimes depends on constitutional settings and technocratic decisions. However, it also hinges on the geographical dynamics of political competition at the national, regional, and local level. The amalgam of the main components of the electoral system (assembly size, district magnitude, allocation formulas, and ballot structures) shapes the level of spatial heterogeneity and the incentives for political competition. Indeed, it not only affects candidates' incentives to campaign on personal rather than party reputation (Carey and Shugart 1995), but also the candidates' incentives to target their efforts to local or national interests.

Hence, wherever politicians compete for broad and spatially-scattered constituencies, officeholders have substantial incentives to provide national (non-targeted) public goods (for instance, national programs for poverty alleviation, social protection networks, or federal infrastructure projects), and apparently to increase the size of the central government (i.e. national-level patronage). On the contrary, if electoral success depends on narrow and geographically-concentrated constituencies, the officeholders have strong incentives to provide locally-targeted public goods (for instance, direct transfers to local governments to build small public projects, local bureaucracies' salaries, or operational costs of running health system at the local level). 
This article contributes to the political economy literature by arguing that the spatial dynamics of electoral politics accounts for cross-national differences in the composition of government spending. In fact, politicians and political parties accommodate their electoral strategies and organizational structures to spatially-defined political incentives (Ames 1995, 1987, 2001). Such adjustment has direct consequences on fiscal politics because office-holders will seek to feed their career ambitions (i.e. reelection, executive positions, etc.) by providing fiscal benefits to their targeted constituencies.

The article is organized as follows. First, I present a theoretical overview on the effects of electoral geography on the patterns of government spending. Particularly, I rely on literature in political economy and comparative politics that have investigated the relationship between electoral systems and economic policy outcomes. Based on this literature, I present a theory on the effect of electoral performance on fiscal politics. In section 2, I describe the data, define variables of interest, and discuss some methodological issues. In section 3, I discuss the results of the statistical models. Finally, in section 4, I finish with some concluding remarks.

\section{Electoral Geography and Fiscal Politics}

Scholars in comparative political economy have shown special interest in the study of the spatial patterns of electoral politics and its implications for representation and distribution (Schattschneider 1975; Stokes 1965, 1967; Sundquist 1973; Brady 1985; Bartels 1988; Brady, Cogan, and Fiorina 2000; Haggard and McCubbins 2000). There has been extensive work on the geographical patterns of voting in Europe (Caramani 2004, 2005, 2011; Lago-Peas and Lago-Peas 2009; Bochsler 2010), Western democracies (Ishiyama 2002; Chhibber and Kollman 2004; Morgenstern, Swindle, and Castagnola 2009; Franzese, Nooruddin, and Long Jusko 2004; Brancati 2008), and Latin America (Jones and Mainwaring 2003; Morgenstern and Potthoff 2005; Gelinau and Remmer 2006; Alemn and Kellam 2008; Harbers 2010). These studies focused on the distribution of parties' support across electoral districts and its effect on democracy, political representation, party stability, and policymaking (Jones and Mainwaring 2003; Morgenstern and Potthoff 2005; Morgenstern and Swindle 2005; Morgenstern, Swindle, and Castagnola 2009). Other scholars have extensively examined the political and economic causes of such geographical patterns of voting 
(Chhibber and Kollman 2004).

The existing literature has favored the use of party nationalization as a concept and measure of the territorial structure of electoral politics. In general terms, they define party nationalization as the degree to which the distribution of party votes across electoral districts is more or less homogeneous (Morgenstern, Swindle, and Castagnola 2009). The concept of party nationalization describes the dynamics of party competition across sub-national units or electoral districts. High levels of party nationalization indicate that electoral competition follows similar patterns across districts in a particular country, while low levels of party nationalization indicate that electoral competition is more heterogeneous across sub-national units (Jones and Mainwaring 2003). In other words, the concept of party nationalization describes the level of homogeneity in voting across electoral districts.

Although the literature on the causes and dynamics of party nationalization is relatively large, only few scholars have studied the effects of static and/or dynamic party nationalization on fiscal policymaking and particularly over the distribution of public spending (Hicken 2009; Hicken, Kollman, and Simmons 2008; Hicken and Simmons 2008; Lago-Peas and Lago-Peas 2009). This is not, of course, a trivial omission for the study of fiscal politics. In fact, substantial evidence suggests that the degree of homogeneity in the spatial distribution of electoral support will shape politicians' strategies, ambitions, targets, and the amount of benefits they are willing to distribute (Stokes 1967; Carey and Shugart 1995; Jones and Mainwaring 2003). Consequently, the concept of party system nationalization is relevant for the study of distributional incentives in electoral politics.

In countries where party systems are highly nationalized (i.e. parties' electoral performance across electoral districts is more homogeneous), the legislators will prioritize national issues in order to get reelected; the president might have greater ability to build legislative coalitions focused on national issues, and the subnational governments (and local politicians) will remain loyal to national partisan structures. Therefore, policy outcomes will be more universalistic.

On the contrary, in countries where party-system nationalization is low (parties' electoral performance across electoral districts is more heterogeneous), partisan leadership will have less control over other party members. Legislators and local politicians will have more incentives to seek personal vote, and the president will need to negotiate legislation with individual legislators or small groups of them (rather than 
party leaders). Therefore, policy outcomes will be more targeted and policymaking process will be more responsive to local and particularistic interests.

Thus, the spatial distribution of the parties' electoral support shapes the likelihood that geographical units will be treated equally in the process of allocation of transfers, public investments, and subsidies (Stein et al. 2005, 40). On the one hand, the number of veto players involved in the policymaking process seems to increase as the spatial heterogeneity of electoral competition increases. On the other hand, such heterogeneity adjusts the dynamics of political competition at the district level by assigning different levels of policy relevance to regional and local partisan structures.

Thus, I argue that the prevalence of weak linkages between the national and local components of the party system (regionalization) increases the likelihood that politicians derive utility from the provision of transfers (locally-targeted public spending). On the contrary, in nationalized party systems, politicians derive utility from the provision of national investments in infrastructure, social protection networks, or poverty alleviation programs (broad, non-targeted public spending). Therefore, one would expect that:

H1: In nationalized party systems (high levels of party nationalization), the central government spending will be more focused on national, broad, non-targeted budget allocations.

H1.A: In regionalized party systems (low levels of party nationalization), the central government spending will be focused on targeted transfers to subnational governments.

However, the argument that the spatial structure of electoral politics affects fiscal policy outcomes will be incomplete without analyzing the dynamics of coalition formation in congress. (Bawn and Rosenbluth 2006; Rosenbluth and Bawn 2006; Persson, Tabellini, and Roland 2003). In highly fragmented legislatures, policymakers do not fully internalize the costs of taxation (expenditures are targeted to small constituencies while taxes are spread over a large amount of citizens) and public spending will probably increase (Kontopoulos and Perotti 1999; Amorin Neto and Borsani 2004). In fact, some scholars offer substantial empirical evidence that proportionalrepresentation electoral systems tend to produce multi-party governments and make the fiscal policymaking process more complicated because of the increasing number 
of veto players. Consequently, the central government must distribute more targeted funds (pork barrel projects or local patronage) in order to build stable legislative coalitions (Persson and Tabellini 2003; Edwards and Thames 2007).

Therefore, the size of the president's legislative coalition actually affects fiscal policy outcomes. The influence of the president over fiscal policymaking will be higher if he controls more seats than needed for a simple majority because he will be less susceptible to particularistic demands from individual legislators. Otherwise, the president will need to transfer more resources to particular electoral districts in order to build his own stable coalition in congress and get policies approved. Consequently, one can hypothesize that:

H2: The larger the president's coalition in congress, the greater the president's ability to coordinate cabinet members as regards spending policy, and therefore, the lower the level of public spending on transfers from central government to subnational governments.

Observe that, in the context of presidential systems, the size of the president's coalition (or party) in the legislature "indirectly captures legislative fragmentation" (Amorin Neto and Borsani 2004). After all, higher fragmentation implies that any coalition is likely to be smaller, including the president's coalition (Amorin Neto and Borsani 2004; Bawn and Rosenbluth 2006). Smaller presidential coalitions (i.e. minimum winning coalitions) create conditions for legislative gridlock and amplify individual legislators' bargaining position for budget negotiations. As the size of the presidential coalition decreases, the president will face two policy alternatives: to avoid meaningful changes in fiscal policy, or to offer more benefits to individual legislators in order to pass legislation. In the first case, there will be a strong bias in favor of the status quo. In the second case, the president will need to offer larger amounts of targeted spending to specific electoral districts or geographical units in order gain legislative support for his spending policies.

This theoretical framework contends that the effect of party nationalization over the composition of central government spending is not isolated from the president's ability to deal with collective action problem in the assembly. I argue that the effect of the spatial structure of electoral politics on type of spending is always conditioned by the size of the president's coalition (party) in congress. 
Table 1: Electoral Politics and Transfers to Subnational Governments

\begin{tabular}{llcc}
\hline \hline & & \multicolumn{2}{c}{ Party Nationalization } \\
\cline { 3 - 3 } Size of Coalition & Low & High \\
\cline { 3 - 3 } & Small & High level & Medium Level \\
& Large & Medium Level & Low Level \\
\hline \hline
\end{tabular}

Table 1 shows that fiscal policy outcomes are quite different if we consider the interactive effect between party nationalization and the size of the president's coalition in congress. The amount of transfers from central to subnational units of government will increase in two different circumstances. First, transfers will increase if the degree of party nationalization is low and the size of the president's coalition is small because fiscal politics becomes more local and geographically dispersed. Thus, politicians will face up particularly narrow electoral motivations. On the other hand, transfers will increase moderately if the party system is highly nationalized but the size of government the president's coalition is still small. The effect of high party nationalization on transfers (described by the hypothesis 1 ) will be attenuated because, as the president's coalition in the legislature gets smaller, there will be more veto players participating in the bargaining process.

One can expect the opposite effect if the size of the president's party (or coalition) in congress increases. The central government's transfers to subnational governments will decrease substantially as the party system becomes more nationalized, and the size of government coalition rises. Such decline would be less severe if party nationalization is low because the predominance of regional interests diminishes central government's discretion over the geographical distribution of spending.

In sum, the spatial patterns of electoral competition and party system organization affect the size and composition of central government spending. However, this is not the end of the story in presidential regimes. The impact of coalitional politics on policy bargaining is not a minor issue. In presidential regimes - in which presidents have substantial powers to initiate, influence, and control the lawmaking process-, the size of the president's coalition in congress has an unquestionable influence on fiscal outcomes. Indeed, some scholars have shown that the policy and productivity weights of the president "varies over time, resulting not only from fixed institutional rules regulating the conditions under which a president may propose legislation, but also from contextual factors affecting how presidents make deals in Congress and 
what prerogatives actually emerge as relevant" (Aleman and Calvo 2010). Those contextual factors are significantly shaped by the dynamics of coalitional politics.

\section{Data and Methods}

\section{Types of Government Spending}

I test my theoretical claims with data from seven Latin American countries, from 1990 to 2006, the broadest time period for which I could get data on all of the variables described below. The dependent variables are two specific types of government expenditure in a given year (measured as a fraction of GDP): targeted spending (transfers from central to subnational governments) and non-targeted spending (nationally-oriented spending programs).

By focusing on particular types of spending, my predictions about spending become contingent upon what kind parties are in government (i.e. nationalized or regionalized parties) and how many of them composed the president's coalition.

Targeted spending is measured as the total sum of central government transfers (or grants) to subnational governments every fiscal year (as percentage of the GDP). ${ }^{1}$ Grants are compulsory and non-compulsory current or capital transfers. Current grants are those made for purposes of current expense and are not linked to or conditional on the acquisition of an asset by the recipient. Capital grants involve the acquisition of assets by the recipient and may consist of a transfer of cash that the recipient is expected or required to use to acquire an asset or assets (other than inventories), the transfer of an asset (other than inventories and cash), the cancellation of a liability by mutual agreement between the creditor and debtor, or the assumption of another unit's debt.

This category of spending is harder to measure in comparable ways across countries because of the complex relationship between federalism and decentralization. Federalism is often accompanied by decentralization, but it is not a necessary condition for decentralization, nor is decentralization a sufficient condition for federalism. In federal countries, there are constitutional or statutory provisions assuring block grants to subnational governments. Such grants can be discriminate between funds

\footnotetext{
${ }^{1}$ This includes direct transfers and all kind of indirect transfers administrated by decentralized funds.
} 
granted local governments in block transfers or with instructions on how to spend. Provinces or states are not necessarily autonomous in unitary countries, but it does not imply that the fiscal process is totally centralized.

To avoid these problems I collected information on the total sum of central government transfers (or grants) to subnational governments every fiscal year (as percentage of the GDP or as percentage of the total current expenditures) directly from governmental sources. I checked in detail the public reports published by the following agencies: Secretaria de Hacienda, Ministerio de Economía y Finanzas Públicas (Argentina); Ministerio de Fazenda and Ministério do Planejamento, Orcamento e Gestão (Brazil); Dirección de Presupuestos - Ministerio de Hacienda (Chile); Ministerio de Hacienda y Crédito Público and Departamento Nacional de Planeación (Colombia); Secretaria de Hacienda y Crédito Publico (Mexico); Ministerio de Economía y Finanzas (Uruguay); and Ministerio del Poder Popular de Planificación y Finanzas (Venezuela).

The non-targeted spending is difficult to measure because it is not easy to discriminate which budget allocations are really under the control of the central government and serve its policy priorities. Thus, we should use a proxy indicator of the central government's discretion to spend. A good measure of such ability is the net amount of resources that the central government spends paying all public employment (as a percentage of GDP).

Wages and salaries consist of all compensation of central government employees except for social contributions by employers. ${ }^{2}$ Excluded are amounts payable to contractors, self-employed outworkers, and other workers who are not employees of central government units (such amounts are usually recorded under use of goods and services). This is an alternative but very effective measurement because it gauges

\footnotetext{
${ }^{2}$ This category includes payments in cash to employees in return for services rendered, basic wages and salaries; cost of living allowances; bonuses; annual supplementary pay, such as "13th month" pay; allowances for transportation to and from work; holiday pay for official holidays or annual holidays; and housing allowances. It also includes other payments in kind as meals and drinks, including those consumed when traveling on business; housing services or accommodation; uniforms or other forms of special clothing that employees choose to wear frequently outside of the workplace as well as at work; the services of vehicles or other durables provided for the personal use of employees; sports, recreation, or holiday facilities for employees and their families; transportation to and from work; car parking; and day care for the children of employees. Also included is the value of interest foregone when loans are provided to employees at reduced or zero rates of interest. I consider a broad definition of social contributions as payments, actual or imputed, made by the central general government units to social insurance schemes to obtain entitlement to social benefits for their employees, including pensions and other retirement benefits.
} 
the central government capacity to allocate resources in spending programs under its direct control.

Table 2 shows some descriptive statistics on these policy outcomes. The average amount of transfers from central to subnational governments as percentage of the GDP is about $5 \%$, ranging from $1.5 \%$ to $11.8 \%$ of the GDP. The amount of transfers as a percentage of the GDP is higher in Argentina and Colombia where subnational governments have weakly institutional structures for tax collection and depend substantially on central government transfers. The average amount of the transfers in the region increases to almost $9 \%$ when we included subsidies granted to regionallybased interest groups (subsidies for companies, farmers, etc.). Meanwhile, the average amount of fiscal resources allocated to non-targeted spending is about $9 \%$ of the GDP, ranging from $3.7 \%$ to $13.7 \%$ of the GDP.

Table 2: Types of Central Government Expenditures as Percentage of the GDP, 7 Countries Latin America, 1990-2006

\begin{tabular}{|c|c|c|c|c|c|c|}
\hline Variable & & Mean & $\overline{\text { S.D. }}$ & Min & Max & Observations \\
\hline \multirow{3}{*}{$\begin{array}{l}\text { Transfers } \\
(\% \text { GDP })\end{array}$} & Overall & 4.99 & 2.71 & 1.50 & 11.80 & $\mathrm{~N}=100$ \\
\hline & Between & & 2.58 & 2.34 & 8.80 & $\mathrm{n}=7$ \\
\hline & Within & & 1.10 & 0.96 & 7.98 & T-bar $=14.29$ \\
\hline \multirow{3}{*}{$\begin{array}{l}\text { Transfers } \\
\text { plus subsidies } \\
(\% \text { GDP) }\end{array}$} & Overall & 8.85 & 1.95 & 3.69 & 13.74 & $\mathrm{~N}=112$ \\
\hline & Between & & 0.94 & 7.24 & 10.08 & $\mathrm{n}=7$ \\
\hline & Within & & 1.75 & 4.54 & 13.71 & T-bar $=16$ \\
\hline \multirow{3}{*}{$\begin{array}{l}\text { Wages } \\
\text { (\%GDP) }\end{array}$} & Overall & 3.19 & 1.19 & 1.18 & 5.15 & $\mathrm{~N}=112$ \\
\hline & Between & & 1.23 & 1.57 & 4.56 & $\mathrm{n}=7$ \\
\hline & Within & & 0.36 & 1.81 & 4.25 & $\mathrm{~T}-\mathrm{bar}=16$ \\
\hline
\end{tabular}

In general, the data available on fiscal performance for the region is dodgy, with large amounts of missing -or untrustworthy - data, and generally, there is extremely limited information about the central government operations. For example, the Government Finance Statistics published annually by the International Monetary Fund (International Monetary Fund 2010) provide comprehensive data about the governments financial operations but do not offer reliable data on the amount of budget allocations transferred from central to subnational governments, especially for nonOECD countries. ${ }^{3}$

\footnotetext{
${ }^{3}$ The political character of the database creates serious problems of reliability. On one hand,
} 
Given these constraints, the best alternative to avoid measurement problems is to collect data directly from the finance ministries in the region and check their consistency with other domestic (i.e. comptroller's office, central banks) and international (IMF, World Bank, ECLAC) data sources. Accordingly, I have collected data directly from ministries of finance in Argentina, Brazil, Chile, Colombia, Mexico, Uruguay, and Venezuela. The dataset includes detailed information about the central government transfers to subnational governments, budget allocations for subsidies, wages paid to national level bureaucracy, and level of public debt for the period 1990-2006.

The selection of countries allows us to get good statistical information because data from ministries could be contrasted with data produced by other institutions, and the inconsistencies were minimal. This sample selection also guarantees a good amount of variation in terms of country size, economic structure, and policy consistency. The issue of policy consistency is crucial in assessing the validity of the statistical analysis because the inclusion of countries with different levels of policy consistency allows us to isolate the effect of the recent structural reforms over policy outcomes. On one hand, I have included countries as Argentina, Uruguay, and Venezuela that recently switched from market-oriented to protectionist/statist economic policies. On the other hand, the dataset also includes countries as Brazil, Chile, and Colombia that have been relatively consistent -at different levels - with free-market policies over time, even after the international economic crises in 1998, 2001, and 2008. They implemented similar trade reforms, changed their tax structure, opened their economies to the global markets, were relatively moderate privatizing public companies, liberalized their labor markets, and opened their financial markets (Lora 2007). ${ }^{4}$

Finally, this sample of countries provides important variability in terms of size of

some countries did not report their official data to the IMF for long periods of time (i.e. Brazil). On the other hand, some national authorities have misreported their data in order to improve their chances of getting more loans from multilateral agencies.

${ }^{4}$ All of them have been relatively successful in transforming their economic structure from being raw material exporters in the first half of the twentieth century to become into diversify economies with unquestionable exporting vocation. This is especially prominent in the case of Brazil, which has become one of the most promising developing economies in the global context. After several years of protectionism and the predominance of ISI policies, they have become regional leaders (at different scales, obviously) of free trade and financial liberalization policies. Indeed, they have reported positive rates of economic growth in the last twenty years - except in 1998 after the world crisis provoked by the fall of the East Asian economies and more recently after the world crisis provoked by the economic downturn of the U.S. economy. 
population, population density, and type of fiscal decentralization. Indeed, this sample includes large (Brazil, Mexico), medium (Colombia, Argentina), and small-size (Chile, Uruguay) countries; highly-dispersed (Brazil, Colombia) and highly-concentrated populations (Argentina, Chile); and, most importantly, this sample includes federal (Argentina, Brazil, Mexico), highly-decentralized (Colombia), and highly-centralized (Chile) fiscal structures.

\section{Party system nationalization}

Party nationalization is not an easy variable to measure. In fact, the debate on measurement problems has been long and only recently scholars seem to reach some type of consensus (Morgenstern, Siavelis, and Polga-Hecimovich 2011). Jones and Mainwaring (2003) propose a variation of the traditional Gini coefficient in order to assess the extent in which a party wins equal vote shares across all the sub-national units. Basically, they use an inverse measure of the Gini coefficient called Party Nationalization Score -PNS- (Jones and Mainwaring 2003, 142). Other authors have worked on indexes based on the effective number of parties (ENP) at the national and district level (Cox 1999), or the standard deviation of party returns across electoral districts (Caramani 2004; Lago-Peñas and Lago-Peñas 2009; Hicken 2009; Hicken, Kollman, and Simmons 2008) .

More recently, some authors have created more complex measures of the level of party nationalization. On one side, Kasuya and Moenius (2008) provide a twodimensional conceptual map of party nationalization consisting of two factors "inflation" and "dispersion". "The former refers to the extent to which the average size of the district-level party systems is inflated to the national level", meanwhile "the latter refers to the extent to which the contribution to each district's party system to the size of national level party system varies across district" (Kasuya and Moenius 2008, 127). Based on that conceptualization, they developed a measure to gauge the degree of party nationalization as a weighted measure of both inflation and dispersion.

This measurement is similar to the PSN developed by Jones and Mainwaring (2003) but is built on the variation of district-level inter-party competition rather than from the variation in the strength of individual parties (Kasuya and Moenius 2008, 131). According to the authors, this slight difference allows the assessment to the degree in which each geographic unit contributes to party system nationalization. 
Morgenstern, Swindle, and Castagnola (2005; 2009) propose a two-dimensional conceptualization of party system nationalization. Unlike Kasuya and Moenius (2008), they focus on the geographic distribution of a party's vote and its degree of consistency across time. In that sense, they argue that nationalization should be considered as a static concept when it refers to geographic distributional issues and a dynamic concept when it refers to changes from one election to another. In this case, party nationalization results from circumstances in which both static and dynamic nationalization are high and the distribution of voters is relatively homogeneous.

Otherwise, we can consider the different combinations of static and dynamic nationalization as special cases of the evolution of the party system: locally-focused parties, unbalanced parties, and parties in flux (Morgenstern and Swindle 2005; Morgenstern, Swindle, and Castagnola 2009). Based on this innovative definition of party nationalization, the authors build a new measurement that combines the two components mentioned above and contend that, under proportional representation, political parties will have higher scores on the static/distributional scale and have no effect on dynamic nationalization.

Following this line of argumentation, I have used the static/distributional score to analyze the impact of party nationalization on fiscal policy outcomes. Calculating the scores is relatively simple but requires significant statistical procedures. First, we calculate the level of district-heterogeneity for every party expressed as the variance of the average values that ever party won across districts the column of averages. In order to calculate such variance, I have run multi-level mixed-effect models for every party at every election from 1990 to 2006. Second, I calculated the square root of these values which corresponds to the standard deviation of the average electoral returns across districts. Then, I reversed and standardized every value so that larger numbers imply greater static/distributional nationalization. Finally, I calculated party-system averages for every country between 1990 and 2006 .

The values of party-system static nationalization range between -0.76 (less nationalized party system) and 0.51 (most nationalized party system). The variation in party nationalization is quite high for this sample. For example, Brazilian party system was highly regionalized in the 1990s but after Lula's election in 2003, the political parties have increasingly become nationalized. The pattern is more stable in Chile where both rightist and leftist coalitions are highly nationalized. On the contrary, Colombia's party system is highly regionalized, especially after the 1991 
constitutional reform.

\section{The president's coalition in the legislature}

The second hypothesis of this paper considers the impact of the dynamics of the coalitional politics in Congress and the president's ability to transform his preferences into policies. The size of the president's coalition (or party) in the legislature shapes the central government's ability to pass legislation and the distributional features of such policies. Thus, one would agree that the president's coalition size is a significant and robust determinant of fiscal outcomes and it affects particularly the amount of transfers allocated to subnational units of governments - obviously, it depends on the number of members of the coalition and their incentives for party/coalition discipline (Perotti and Kontopoulos 2002).

Table 3: Types of Central Government Expenditures as Percentage of the GDP, 7 Countries Latin America, 1990-2006

\begin{tabular}{llccccl}
\hline \hline Variable & & Mean & Std. Dev. & Min & Max & Observations \\
\hline Static Party & Overall & 0.00 & 0.25 & -0.76 & 0.51 & $\mathrm{~N}=119$ \\
Nationalization & Between & & 0.01 & -0.02 & 0.02 & \\
& Within & & 0.25 & -0.74 & 0.54 & \\
& & & & & & \\
Size of Government & Overall & 0.57 & 0.18 & 0.17 & 1.00 & $\mathrm{~N}=119$ \\
Coalition & Between & & 0.08 & 0.47 & 0.71 & \\
& Within & & 0.16 & 0.13 & 1.09 & \\
Primary Fiscal & & & & & & \\
Balance (\% GDP) & Overall & -1.41 & 2.41 & -7.56 & 7.69 & $\mathrm{~N}=112$ \\
& Within & & 1.63 & -3.40 & 1.52 & \\
Economic Growth & & 1.85 & -6.60 & 4.76 & \\
Rate & Overall & 3.40 & 4.66 & -11.03 & 18.29 & $\mathrm{~N}=119$ \\
& Between & & 1.04 & 2.30 & 5.52 & \\
\hline \hline
\end{tabular}

I evaluate the impact of the size of the president's coalition by using the World Bank's majority index. This index measures the fraction of seats held by the government every legislative period. It is calculated simply by dividing the number of government seats by total (government plus opposition plus non-aligned) seats (Beck et al. 2001). The average size of the president's coalition is $57 \%$ and ranges from $17 \%$ to $100 \%$ (please see Table 3). 


\section{Alternative Explanations}

Once I examine the interactive effect that both party nationalization and the size of the president's coalition have on central government's spending priorities, the next step is to consider how structural factors affect the central government's fiscal priorities. On one hand, the composition of the public spending is not independent of the central government's ability to manage fiscal policy. Poor fiscal governance not only affects macroeconomic performance but it also changes fiscal priorities adding macroeconomic constraints to the allocation of public resources.

Consequently, this model also evaluates how budget deficits shape the incentives to provide different types of public goods. Thus, to measure the impact of public governance on the composition of public spending, I estimate the effect of primary fiscal balance (as a percentage of the GDP) on the budget allocation for targeted and non-targeted programs. The data for primary balance was also collected directly from the information provided by the ministries of finance at each country and validated with data sources generated by domestic central banks.

Finally, the statistical model assesses the impact of structural economic conditions on the composition of the central government spending. In particular, I evaluate the effect of economic cycles on the allocation of public resources. To measure this I have included the annual rate of economic growth for each country in the sample in the period 1990-2006.

\section{Estimation}

Given the structure of the data described above, I estimated a fixed-effects crosssectional model and ran LM tests for serial correlation among contemporaneous residual disturbances across each sectional unit. The LM statistic is based on the OLS residuals for the $i j t h$ residual correlation coefficient representing the off-diagonal elements of the variance-covariance matrix of the model's estimates parameters. According to the results of this test, one can reject the null hypothesis that there is no first-order serial correlation ( $\mathrm{p}$-value $=0.000$ ). The test for serial correlation in the idiosyncratic errors of a linear panel-data model (Wooldridge 2002) indicates that there is a meaningful serial correlation problem. Thus, the model was corrected for serial correlation of the error term. The statistical procedures guarantee the statistical robustness of the results and the accuracy of the estimates . 


\section{Results}

Table 4 presents the results with fiscal outcomes as dependent variables. Models 1 to 3 evaluate the impact of party nationalization and size of government coalition on the central government's trade-off between targeted and non-targeted budget allocations. Every model includes an interaction term in order to evaluate the joint effect of nationalization and coalition size.

As predicted by the theory framework, the first model shows that party nationalization has a negative effect on the level of transfers from central to subnational governments. The coefficient for static party nationalization is negative and significant, which supports the first hypothesis that increasing party system static-nationalization reduces the amount of targeted transfers from central to subnational levels of government. Consistent with my expectation, the first model also suggests that the net amount of targeted transfers (as percentage of the GDP) will decrease as the size of government coalition in congress increases. Indeed, it suggests that the incentives for the central government to distribute resources based on geographical considerations are less intense as the government coalition becomes larger in the legislative floor. Even more important, the fixed-effects model strongly suggests that my theory of how spatial patterns of electoral competition affect the composition of public expenditures is relevant not only for explaining cross-national variation, but also for explaining within-country temporal variation.

At the same time, the model suggests that the effect of party nationalization on fiscal outcomes is greater than the one produced by the size of the president's coalition in the legislature. In fact, for every one-percent increase in the size of the president's coalition, the transfers will decrease about $1.4 \%$, meanwhile for every oneunit increase in the normalized-scale of static party nationalization, the amount of transfers decreased about $2.5 \%$ as percentage of the GDP.

Turning to structural-economic variables, we also find that reducing fiscal deficits would have a negative impact on the amount of transfers granted by the central government to subnational units. It seems that responsible fiscal governance (the government's ability to reduce fiscal deficit or reach fiscal surplus) seems to diminish

the importance of targeted spending programs in the central government's expenditures, at least as percentage of the GDP. This finding not only suggests that fiscal surplus would allow government to increase the funding for national, broad spend- 
Table 4: Cross-Sectional Time-Series Regression Models for Central Government Type of Expenditure, Fixed-effects (within) Regression Estimator

\begin{tabular}{lccc}
\hline \hline & Transfers & Transfers and Subsidies & Wages \\
& $b /(s . e)$ & $b /(s . e)$ & $b /(s . e)$ \\
\hline \multirow{2}{*}{ Static Party Nationalization } & $-2.495^{*}$ & $-4.681^{* * *}$ & $1.060^{* *}$ \\
& $(1.487)$ & $(2.172)$ & $(0.463)$ \\
Size of Government Coalition & $-1.389^{* *}$ & -0.626 & 0.243 \\
& $(0.607)$ & $(0.910)$ & $(0.194)$ \\
Interaction Term & & & $-1.473^{*}$ \\
& $\left(2.670^{* *}\right.$ & $12.74^{* * *}$ & $(0.813)$ \\
Primary Fiscal Balance & $-0.182^{* * *}$ & $(3.818)$ & $-0.084^{* * *}$ \\
& $(0.065)$ & $-0.309^{* * *}$ & $(0.019)$ \\
Economic Growth & & $(0.091)$ & -0.005 \\
& -0.014 & & $(0.008)$ \\
Constant & $(0.024)$ & 0.028 & $2.957^{* * *}$ \\
& & $(0.036)$ & $(0.128)$ \\
\hline Observations & $5.494^{* * *}$ & $8.586^{* * *}$ & 112 \\
R-squared & $(0.393)$ & $(0.599)$ & 0.26 \\
\hline \hline
\end{tabular}

${ }^{* * *} \mathrm{p}<0.01,{ }^{* *} \mathrm{p}<0.05,{ }^{*} \mathrm{p}<0.1$

ing programs, but also that there is a strong relationship between responsible fiscal governance and fiscal centralization (Hallerberg, Strauch, and Von Hagen 2009).

In order to test the robustness of these results, I estimated this model using other measurements of party nationalization as the coefficient of variation -mean deviation from the average percentage of votes obtained by parties at each subnational unit (Caramani 2004; Kasuya and Moenius 2008)- and the party nationalization scores (Jones and Mainwaring 2003). In both cases, the results are consistent with the model presented in Table 4 and strongly corroborated my argument concerning the negative effect of party nationalization on the amount of fiscal resources transferred from national to subnational units of government.

As a second test of robustness, the model 2 in Table 4 evaluates the effect of party nationalization on the sum of targeted transfers to subnational governments and targeted subsidies to regionally-oriented interest groups (as percentage of the GDP). 
The effect is still statistically significant and persistently negative. The amount of transfers and subsidies decreases as the party system becomes more nationalized and the size of the president's coalition increases. In fact, in this case, the negative effect of party nationalization is even greater: for every one-unit increase in party system nationalization, the amount of transfers and subsidies as percentage of the GDP decreases almost $5 \%$.

The analysis of the central government's trade-off between targeted and nontargeted budget allocations would be incomplete without estimating the effect of the main explanatory variables on targeted, broad, and national spending programs. If party system nationalization and the size of the president's shape fiscal policy tradeoffs, they should affect the provision of non-targeted goods in the opposite way that they affect the provision of targeted goods. Otherwise, such trade-off does not exist.

As mentioned before, the non-targeted spending represents all goods, services, and wages the government devotes to provide broad, national-oriented spending programs. The size of the central government rises as the non-targeted spending increases. Thus, any indicator of the size of central government is a good indicator of the amount of fiscal resources allocated for non-targeted expenditures. The data available for the amount of fiscal resources that central governments in Latin American use to buy goods and services is fragmentary and many times quite messy - for example, the IMF's Government Finance Statistics database has serious gaps and inconsistencies. These problems cannot be solved using data directly extracted from the finance ministries because there are important gaps for some of the countries in the sample. However, the data on central government's current expenditures on wages paid to national-level bureaucracy are available, reliable, and constitute a good measure of the importance of nationally-oriented spending programs.

The third model in table 4 evaluates the effect of party system nationalization and size of the president's coalition on the amount of wages under direct control of the central government (as percentage of the GDP). The model suggests that current expenditures on national-level wages increase as the party system becomes more nationalized. That is, the central government allocates more resources to national, broad spending programs as the citizens' support for political parties becomes more equally distributed across electoral districts. On the other hand, the model 3 also shows that the size of president's coalition has a positive effect on non-targeted expenditures; however, such effect is not statistically significant. Therefore, as suggested by 
my theory, the provision of non-targeted expenditures increases as the party system becomes more nationalized and the president's coalition in the legislature increases its size.

My second theoretical claim is that there is a joint effect of party system nationalization and the size of president's coalition on the composition of central government expenditures. Figure 1 presents the predicted values of targeted expenditures as they vary with increasing party system nationalization for different levels of observed government coalition size (ranging between $15 \%$ and $100 \%$ of the total of legislative seats).

As predicted in the theory section, the effect of party system nationalization on fiscal policy outcomes are strongly conditioned by the size of government coalition. The panels in Figure 1 show that the amount of targeted transfers (as percentage of the GDP) decreases as party system nationalization (standardized) increases, while the amount of targeted expenditures (as a percentage of the GDP) increases as the party system nationalization (standardized) increases. However, the model predicts that the amount of non-targeted expenditures is significantly bigger than the amount of targeted expenditures as the size of government coalition increases from $15 \%$ to $100 \%$. That is, the enlargement of the president's coalition in congress reinforces the effect of party system nationalization making non-targeted expenditures (national, broad spending programs) more substantial than targeted transfers. As I mentioned before, large-size legislative government coalitions vest the central government with more fiscal discretion to impose its own policy preferences. At high levels of partysystem nationalization central government will prefer larger amounts of non-targeted expenditures, while at low levels of party system nationalization it will prefer larger amounts of targeted transfers to subnational units of government.

Consistent with my theoretical expectations, the model also predicts that at the same level of party nationalization any increase in the size of government coalition reduces the amount of targeted distributed by the central government. For example, at the lowest level of party system nationalization - (-0.8) in the standardized scale presented in the Figure 1 -, the amount of transfers distributed to subnational governments decreases from $7.6 \%$ to $6.4 \%$ of GDP when the coalition size rises from $15 \%$ to $100 \%$.

The issue of constitutional federalism is one of the main challenges for explaining government expenditures from a comparative perspective. As mentioned above, 

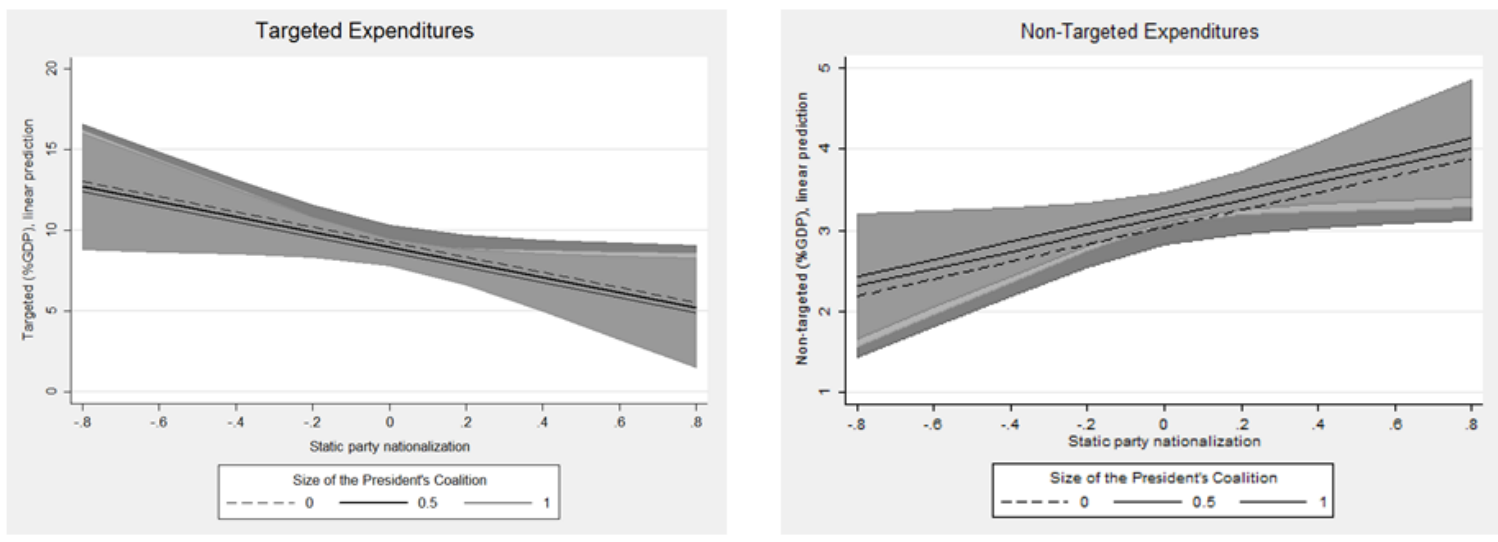

Figure 1: Predicted Values of the Central Government's Type of Spending by Level of Party-System Nationalization Given Different Sizes of Government Coalition.

transfers (targeted spending) from central to subnational governments are usually higher in federal countries.In fact, some scholars argue that fiscal federalism create strong incentives for subnational governments to expand their expenditures while externalizing the costs to others (Rodden, et al. 2001, Von Hagen et al. 2001, IDB 1999). Thus, the inclusion of constitutional federalism would make the statistical results not stand because it would will soak up all the variance generated by other independent variables. In order to test this argument, I introduced a measure of federalism (a dummy variable that takes values of 1 if the country is organized as a constitutional federation) into the main explanatory model and compare the results with the original statistical specification. Table 5 presents the results of this comparison.

I also run the main model using different measures of party nationalization. Unsurprisingly, the effect of the main dependent variables remains the same in terms of direction, almost equal in terms of magnitude, and the differences in terms of significance levels are minimal. The table in Appendix B shows that the effect of party nationalization on the provision of targeted public goods is significant and negative for several measures of party nationalization. This indicated that my results are highly robust.

The results presented in Table 4, 5, Appendix B, and Figure 1 are consistent with my theory of how the geographical patterns of electoral politics have a great deal of impact on public finances and provide strong evidence that electoral politics shapes not only the size but the composition of public expenditures. However, it is 
Table 5: Cross-Sectional Time-Series Regression Models for Central Government Type of Expenditure, including federalism. Fixed-effects (within) Regression Estimator

\begin{tabular}{lcc}
\hline \hline & $(1)$ & $(2)$ \\
& Current transfers & Current transfers \\
\hline Static party nationalization & $-4.681^{*}$ & $-4.681^{*}$ \\
& $(2.172)$ & $(2.215)$ \\
Size of the president's coalition (SPC) & -0.626 & -0.626 \\
& $(0.910)$ & $(0.937)$ \\
Party nationalization*SPC & & \\
& $12.74^{* *}$ & $12.74^{* *}$ \\
Fiscal balance & $(3.818)$ & $(3.995)$ \\
& $-0.309^{* * *}$ & $-0.309^{* *}$ \\
Economic growth & $(0.091)$ & $(0.098)$ \\
& & \\
Constitutional federalism & 0.0275 & 0.0275 \\
& $(0.036)$ & $(0.037)$ \\
Constant & & -0.261 \\
& & $(0.741)$ \\
$\mathrm{N}$ & & \\
$\mathrm{R} 2$ & $8.586^{* * *}$ & $8.728^{* * *}$ \\
\hline \hline$* * * \mathrm{p}<0.01, * * \mathrm{p}<0.05,{ }^{*} \mathrm{p}<0.1$ & $(0.599)$ & $(0.868)$ \\
\hline
\end{tabular}

reasonable to think that the composition of central government expenditures could affect the spatial and legislative dynamics of electoral politics.

For example, if the central government distributes more targeted transfers to subnational governments, one could expect that political parties strengthens their regional and local organizational structures in order to get control over additional fiscal benefits. Such process would be especially intense in those districts receiving large amounts of transfers. Consequently, the composition of public spending and the level of party system nationalization are simultaneously related.

Endogeneity problems can be solved by using different analytical strategies and one of them would require the use of instrumental-variable methods to obtain consistent parameter estimates. In table 5, I have estimated a fixed-effects instrumental- 
Table 6: Cross-Sectional Time-Series Regression Models for Central Government Type of Expenditure, Fixed-effects (within) Instrumental Variables Regression

\begin{tabular}{lcc}
\hline \hline & $\begin{array}{c}\text { Transfers } \\
b /(s . e)\end{array}$ & $\begin{array}{c}\text { Wages } \\
b /(s . e)\end{array}$ \\
\hline Static Party Nationalization & -9.14 & $4.343^{*}$ \\
& $(6.331)$ & $(2.307)$ \\
Size of Government Coalition & $-1.303^{*}$ & 0.156 \\
& $(0.677)$ & $(0.245)$ \\
& $18.21^{*}$ & $-7.002^{*}$ \\
Interaction Term & $(10.95)$ & $(3.897)$ \\
& $-0.178^{* *}$ & $-0.076^{* * *}$ \\
Primary Fiscal Balance & $(0.072)$ & $(0.024)$ \\
& -0.011 & -0.010 \\
Economic Growth & $(0.027)$ & $(0.010)$ \\
& \multicolumn{2}{c}{} \\
Constant & $5.379^{* * *}$ & $3.054^{* * *}$ \\
& $(0.448)$ & $(0.17)$ \\
\hline Instrumented Variable:Static Party Nationalization \\
Instruments: Effective Number of Parties \\
Observations & 100 & 112 \\
\hline \hline *** p<0.01, ** p $<0.05, *$ p $<0.1$ & \multicolumn{2}{c}{}
\end{tabular}

variable (IVLS) regression of transfers and wages for the sample. The effective number of parties provides the instrument for party nationalization. On one hand, there is a positive correlation between the number of parties participating in the electoral contests and the degree of party system nationalization, thus the effective number of party is relevant for party nationalization and passes one key requirement for a good instrument. On the other hand, the effective number of parties is independent of the error term. Thus, the effective number of parties is both relevant and exogenous, which are the main conditions for being a good instrumental variable for party nationalization (Dunning 2008).

The IVLS estimates presented in table 5 suggest the results of the models in table 4 are correct. Increasing party nationalization affect negatively the amount of transfers and positively the amount of non-targeted expenditures. The effect of coalition size remains the same: larger government coalitions reduce targeted expenditures and 
increase non-targeted expenditures. The interactive effect between party nationalization and coalition is the same. Therefore, once we solve for endogeneity problems, the empirical evidence supports the main insights of my theory about the effect of the geographical patterns of electoral performance (party system nationalization) on the composition of government spending in presidential regimes.

\section{Concluding Remarks}

This article offers a new understanding of how and why party-system nationalization changes the preferences of the central government for targeted versus non-targeted expenditures in presidential regimes. While much of the recent literature on the relationship between electoral rules and policy outcomes has focused on the role of electoral rules, I have shown that the geographical patterns of electoral performance have a significant impact on fiscal policy priorities. Indeed, the evidence I presented in this article suggests that party-system regionalization privileges the role of candidates rather than parties in the local context, and consequently, obstructs the bargaining process in congress. Moreover, regionalized party systems reduce the central government's ability to allocate greater amounts of resources in nationally-oriented public goods.

However, the spatial structure of electoral politics does not seem to exert an isolated influence on the type of government spending. The size of president's coalition shapes such effect because the legislative bargaining becomes more expensive as the president's coalition shrinks. This paper shows that the expansion of the president's coalition in congress reinforces the effect of party system nationalization, making non-targeted expenditures (national, broad spending programs) more rewarding than targeted transfers. I demonstrate that, holding party nationalization constant, any increase in the size of president's coalition reduces the amount of targeted distributed by the central government.

The theoretical framework presented here and its empirical implications for Latin American countries fit naturally into a large comparative political economy literature that provides substantive reasons for connecting electoral geography and government spending. The cross-national data analyses provide evidence for the interactive link among party nationalization, coalition size, and type of spending. Although my argument focuses on central versus local control over public expenditures, rather than on 
the trade-off between pork and patronage, this article also provides preliminary but significant clues for the study of the effect of spatial patterns of electoral performance on the classical trade-off between pork and patronage. In fact, some empirical evidence presented in this article suggests the existence of a trade-off between patronage at the national level versus other expenditures at the local level, which can include pork or local patronage.

The theoretical and empirical results presented in this article also suggest encouraging directions for future research. One substantive question is raised: if the territorial structure of electoral politics affects the composition of government spending, does it also affect fiscal balance? I found some evidence that nationalized party systems are less prone to large fiscal deficits than their regionalized peers. Indeed, less nationalized party systems seem more prone to engage into bad fiscal practices, carry out large transfers programs, and be less responsible maintaining fiscal balance. However, this question is more complex and involves other factors not analyzed in this article, i.e., the structure and nature of fiscal decentralization. Some scholars have argued that decentralized countries are more prone to spend more fiscal resources -more transfers to subnational levels of government and less subnational taxation. Consequently, they are more sensitive to fiscal imbalances (Rodden 2006). Unlike fiscally-centralized countries, cutting off expenditures or increasing taxes is substantially more difficult for federations. Despite these significant insights, the linkages between the spatial patterns of electoral performance and fiscal deficit in federalized countries remain unexplored. 


\section{Appendix A}

In this appendix, I am presenting the formulas to calculate different measures of party nationalization. This appendix is quite useful for the readers to understand the nature of the main independent variable and allow them to compare the attributes of the most popular measures.

1. Mean squared deviation (MSD):

$$
V=\frac{\sum\left(X_{i}-\bar{X}\right)^{2}}{n}
$$

Where $X_{i}$ is the percentage of valid vote won by party $\mathrm{X}$ in the $i$ th district; $\bar{X}$ is the average percentage of valid vote won by party $\mathrm{X}$ in all districts; and $n$ is the number of districts

2. Variance:

$$
S^{2}=\frac{\sum\left(X_{i}-\bar{X}\right)^{2}}{n-1}
$$

3. Standard deviation:

$$
S=\sqrt{\frac{\sum\left(X_{i}-\bar{X}\right)^{2}}{n-1}}
$$

4. Variability coefficient:

$$
V C=S / \bar{X}
$$

5. Gini coefficient:

$$
G_{i}=\left(X_{i} Y_{i+1}\right)-\left(X_{i+1} Y_{i}\right)
$$

In this case, $X_{i}$ is the percentage of valid vote won by party $\mathrm{X}$ in the $i t h$ district divided by the sum of percentages won by party $\mathrm{X}$ in all states; $Y_{i}$ is the cumulative proportion that the $i t h$ state represents of the total number of states or other political sub-units.

6. Relative nationalization:

$$
N_{j t}=\frac{\left(\bar{\delta}_{j t}\right)^{2}}{\left(\bar{\delta}_{j t}\right)^{2}+\operatorname{Var}\left(\overline{\delta_{j t}}\right)}
$$

Where $N_{j t}$ represents the distribution of predicted electoral change for party $j$, both systematic and idiosyncratic, from the previous election.

7. Static party-system nationalization:

Morgenstern and Potthoff (2005) propose a modified version of Stokes's componentsof-variance model applied to district-level data. They seek to fix some flaws of 
the Stokes' model (especially, the assumption of fixed effects for the district and state elements) and propose a geographical adjustment to two geographic levels as opposed to three (as in the US). They model a party's electoral performance as follows:

$$
y_{i k}=\mu+A_{k}+B_{i}+C_{i k}(i=1, I ; k=1,, K)
$$

Where,

$y_{i k}$ is the percentage of the total vote received by the political party $y$ in the election in district $i$ at time $k ; K$ is the number of elections; $I$ is the number of districts; $A_{k}$ : is a nationwide random effect for time $k$, assumed to have mean 0 and (unknown) variance $\sigma_{A}^{2} ; B_{i}$ is a random effect (covering all years) for district $i$, assumed to have mean 0 and variance $\sigma_{B}^{2} ; C_{i k}$ is a residual effect, or random interaction effect, for district $i$ and time $k$, assumed to have mean 0 and variance $\sigma^{2}$; and $\mu$ is a fixed effect representing the overall unweighted mean of the party's vote percentages across all districts and elections.

From this model, we can calculate three measures:

$\sigma_{A}^{2}$ : volatility component: the magnitude of a party's change in support over time (Dynamic party nationalization).

$\sigma_{B}^{2}$ : district heterogeneity effect: variation in a party's average returns across districts (Static Party Nationalization).

$\sigma^{2}$ : district-time effect: capturing non-uniform responses to national policy, as well as the importance of candidate characteristics and district peculiarities to the election.

The difference with Stokes' model is that Morgenstern and Potthoff treat 'district heterogeneity effects' as random effects. 


\section{Appendix B}

Table 7: Cross-Sectional Time-Series Regression Models for Different Measures of Party Nationalization, Fixed-effects Regression

\begin{tabular}{|c|c|c|c|c|}
\hline & $\begin{array}{c}(1) \\
\text { Transfers }\end{array}$ & $\begin{array}{c}(2) \\
\text { Transfers }\end{array}$ & $\begin{array}{c}(3) \\
\text { Transfers }\end{array}$ & $\begin{array}{c}(4) \\
\text { Transfers }\end{array}$ \\
\hline $\begin{array}{l}\text { Static party nationalization } \\
\text { (Morgenstern and Potthoff) }\end{array}$ & $\begin{array}{r}-4.360+ \\
(0.058)\end{array}$ & & & \\
\hline $\begin{array}{l}\text { Party nationalization score } \\
\text { (Mainwaring and Jones) }\end{array}$ & & $\begin{array}{r}-5.621+ \\
(0.083)\end{array}$ & & \\
\hline $\begin{array}{l}\text { Party nationalization - variability coeff. } \\
\text { (Caramani) - inversed value }\end{array}$ & & & $\begin{array}{c}-0.427^{* *} \\
(0.006)\end{array}$ & \\
\hline $\begin{array}{l}\text { Relative party nationalization } \\
\text { (Aleman) }\end{array}$ & & & & $\begin{array}{r}-2.658+ \\
(0.082)\end{array}$ \\
\hline Size of the president's coalition (SPC) & $\begin{array}{l}-1.284 \\
(0.172)\end{array}$ & $\begin{array}{l}-0.679 \\
(0.640)\end{array}$ & $\begin{array}{r}-1.555+ \\
(0.092)\end{array}$ & $\begin{array}{l}-1.386 \\
(0.104)\end{array}$ \\
\hline Party nationalization*SPC & $\begin{array}{l}12.79 * * \\
(0.002)\end{array}$ & $\begin{array}{l}3.906^{*} \\
(0.026)\end{array}$ & $\begin{array}{c}4.795^{* * *} \\
(0.000)\end{array}$ & $\begin{array}{c}6.017^{* * *} \\
(0.000)\end{array}$ \\
\hline Constant & $\begin{array}{c}9.485^{* * *} \\
(0.000)\end{array}$ & $\begin{array}{c}13.74^{* * *} \\
(0.000)\end{array}$ & $\begin{array}{c}11.05^{* * *} \\
(0.000)\end{array}$ & $\begin{array}{c}10.59^{* * *} \\
(0.000)\end{array}$ \\
\hline $\mathrm{N}$ & 112 & 95 & 112 & 88 \\
\hline $\mathrm{R} 2$ & 0.215 & 0.109 & 0.246 & 0.341 \\
\hline
\end{tabular}




\section{References}

[1] Alemán, Eduardo, and Marisa Kellam, 2008. The Nationalization of Electoral Change in the Americas. Electoral Studies 27 (2), 193-212.

[2] Alemán, Eduardo, and Ernesto Calvo, 2010. Unified Government, Bill Approval, and the Legislative Weight of the President. Comparative Political Studies 43 (4), 511-534.

[3] Alesina, Alberto, and Roberto Perotti, 1995. Fiscal Expansions and Adjustments in OECD Countries. Economic Policy 10 (2), 207-248.

[4] Ames, Barry, 1995. Electoral Strategy under Open-List Proportional Representation. American Journal of Political Science 39 (2), 406-433.

[5] Ames, Barry, 2002. The Deadlock of Democracy in Brazil. Ann Arbor MI: University of Michigan Press.

[6] Austen-Smith, David, 1988. Elections, Coalitions, and Legislative Outcomes. American Political Science Review 82, 405-422

[7] Bartels, Larry. 1998. Electoral Continuity and Change, 1868-1996. Electoral Studies 17 (3), 301-326.

[8] Bawn, Kathleen and Frances Rosenbluth, 2006. Short versus Long Coalitions: Electoral Accountability and the Size of the Public Sector. American Journal of Political Science 50 (2), 251-265

[9] Beck, Thorsten, George Clarke, Alberto Groff, Philip Keefer, and Patrick Walsh, 2001. New Tools in Comparative Political Economy: The Database of Political Institutions. 15:1, 165-176 (September), World Bank Economic Review.

[10] Bochsler, Daniel, 2010. Territory and Electoral Rules in Post-Communist Democracies. New York: Palgrave Macmillan.

[11] Brady, D. 1985, A Reevaluation of Realignments in American Politics: Evidence from the House of Representatives. American Political Science Review 79, 28-49.

[12] Brady, D., D’Onofrio, R., Fiorina, M., 2000. The Nationalization of Electoral Forces Revisited. In: Brady, D., Cogan, J., Fiorina, M. (eds.). Continuity and Change in House Elections. Stanford CA: Stanford University Press.

[13] Caramani, Daniele, 2004. The Nationalization of Politics: The Formation of National Electorates in and Party Systems in Western Europe. Cambridge: Cambridge University Press. 
[14] Caramani, Daniele, 2005. The Formation of National Party Systems in Europe: A Comparative-Historical Analysis. Scandinavian Political Studies 28 (4), 295322.

[15] Caramani, Daniele. 2011. The Europeanization of Electoral Politics: An Analysis of Converging Voting Distributions in 30 European Party Systems, 1970-2008, Party Politics. Published online before print March 7, 2011.

[16] Chhibber, P. and K. Kollman, 2004. The Formation of National Party Systems: Federalism and Party Competition in Canada, Great Britain, India and the United States. Princeton, N.J.: Princeton University Press.

[17] Cox, Gary, 1999. Electoral Rules and Electoral Coordination. Annual Review of Political Science 2, 145-161.

[18] Cox, Gary, Stephan Haggard and Mathew D. McCubbins, 2000. Presidents, Parliaments, and Policy. New York: Cambridge University Press.

[19] Dunning, Thad, 2008. Model Specification in Instrumental-Variables Regression. Political Analysis 16 (3), 290-302.

[20] Edwards, Martin and Thames, Frank, 2007. District Magnitude, Personal Votes, and Government Expenditures. Electoral Studies (26) 2, 338-345.

[21] Hallerberg, Mark. 1998. Electoral Institutions and the Budget Process. In: Fukasaku, Kiichiro, and Ricardo Hausmann (eds). Democracy, Decentralization and Deficits in Latin America. Paris, France: Inter-American Development Bank/Development Centre of the Organization for Economic Co-operation and Development.

[22] Hallerberg, Mark, Rolf Rainer Strauch, and Jurgen von Hagen, 2009. Fiscal Governance in Europe. New York: Cambridge University Press

[23] Harbers, Inke, 2010. Decentralization and the Development of Nationalized Party Systems in New Democracies: Evidence from Latin America. Comparative Political Studies 43(5), 606-627.

[24] Ishiyama, J. T., 2002. Elections and Nationalization of the Vote in PostCommunist Russian Politics: A Comparative Perspective. Journal of Communist Studies and Transition Politics 18 (3), 29-40.

[25] Jones, Mark P., and Scott Mainwaring, 2003. The Nationalization of Parties and Party Systems: And Empirical Measure and an Application to the Americas. Party Politics 9 (2), 139-66. 
[26] Kontopoulos, and Roberto Perotti, 1999. Government Fragmentation and Fiscal Policy Outcomes: Evidence from OECD Countries. In James Poterba et al. Fiscal Institutions and Fiscal Performance. Chicago: University of Chicago Press.

[27] Kasuya, Y. and J. Moenius, 2008. The Nationalization of Parties and Party Systems: Conceptual Issues and Alternative District-focused measures. Electoral Studies 27, 126-135.

[28] Lago-Peñas, Ignacio, and Santiago Lago-Peñas. 2009. Does the Nationalization of Party Systems Affect the Composition of Public Spending? Economics of Governance 10 (1), 85-98.

[29] Lizzeri, Alessandro, and Nicola Persico, 2001. The Provision of Public Goods under Alternative Electoral Incentives. The American Economic Review 91 (1), 225-239.

[30] Lijphart, Arend, 1994. Electoral Systems and Party Systems: A Study of Twentyseven Democracies 1945-1990. Oxford: Oxford University Press.

[31] Lora, Eduardo, 2001. Reformas estructurales en Amrica Latina: qu se ha reformado y cmo cuantificarlo." RES Working Papers 4294, Inter-American Development Bank, Research Department.

[32] Milesi-Ferretti, Gian Maria, Roberto Perotti, and Massimo Rostagno, 2002. Electoral Systems and Public Spending. The Quarterly Journal of Economics 117 (2), 609-657.

[33] Morgenstern, Scott, and Benito Nacif, eds.,2002. Legislative Politics in Latin America. New York: Cambridge University Press.

[34] Morgenstern, Scott, and Richard F. Potthoff, 2005. The Components of Elections: District-Time Effects, District Heterogeneity, and Volatility. Electoral Studies 24 (1), 17-40.

[35] Morgenstern, Scott, and Stephen M. Swindle, 2006. Are Politics Local? An Analysis of Voting Patterns in 23 Democracies. Comparative Political Studies 38 (2), 143-70.

[36] Morgenstern, Scott, Stephen M. Swindle, and Andrea Castagnola, 2009. Party Nationalization and Institutions. The Journal of Politics 71 (04), 1322-1341.

[37] Morgenstern, Scott, Peter Siavelis, and John Polga-Hecimovich, 2011. Measuring Party System Nationalization: A Cautionary Tale from Chile." Paper Presented at the Annual Meeting of the Midwest Political Science Association, Chicago, IL, March 2011. 
[38] Neto, Octavio, and Hugo Borsani, 2004. Presidents and Cabinets: The Political Determinants of Fiscal Behavior in Latin America. Studies in Comparative International Development (SCID) 39 (1), 3-27.

[39] Perotti, Roberto and Yianos Kontopoulos, 2002. Fragmented Fiscal Policy. Journal of Public Economics 86 (2002), 191-222

[40] Persson, Torsten. 2001. Do Political Institutions Shape Economic Policy? NBER Working Paper, No. 8214

[41] Persson, Torsten, and Guido Tabellini. 2002. Political Economics: Explaining Economic Policy. Cambridge MA: MIT Press.

[42] Persson, Torsten, and Guido Tabellini. 2003. The Economic Effects of Constitutions. Cambridge MA: MIT Press.

[43] Persson, Torsten, Gerard Roland and Guido Tabellini, 2007. Electoral Rules and Government Spending in Parliamentary Democracies. Quarterly Journal of Political Science: Vol. 2:No 2, pp 155-188.

[44] Rodden, Jonathan, 2006. Hamilton's Paradox: The Promise and Peril of Fiscal Federalism. New York: Cambridge University Press.

[45] Roubini, Nouriel, and Jeffrey D. Sachs. 1989. Political and economic determinants of budget deficits in the industrial democracies. European Economic Review $33(5): 903-933$.

[46] Schattschneider, E. 1960. The Semi-Sovereign People. New York: Rinehart and Winston.

[47] Shugart, Matthew Soberg, and John M. Carey. 1992. Presidents and Assemblies: Constitutional Design and Electoral Dynamics. New York: Cambridge University Press.

[48] Shugart, Mathew S. and John M. Carey, 1995. Incentives to Cultivate a Personal Vote: A Rank Ordering of Electoral Formulas. Electoral Studies 14 (4), 417-39.

[49] Stein, E., Tommasi, M., Echebarria, K., Lora, E., and Payne, M. 2005. The Politics of Policies: Economic and Social Progress in Latin America. Washington DC: IADB.

[50] Stein, Ernesto, Ernesto Talvi, and Alejandro Grisanti. 1999. "Institutional Arrangements and Fiscal Performance: The Latin American Experience" in Poterba, James M. , and Jrgen von Hagen (eds.). Fiscal Institutions and Fiscal Performance. Chicago IL: University of Chicago Press. 
[51] Stokes, Donald. 1965. Parties and the Nationalization of Electoral Forces. In Chambers, W.N. and W.D. Burnham (eds.). The American Party System: States of Political Development. New York: Oxford University Press.

[52] Stokes, Donald. 1967. Parties and the Nationalization of Electoral Forces. In: Chambers, W., Burnham, W. (eds.). The American Party Systems: Stages of Political Development. New York: Oxford University Press.

[53] Sundquist, J. 1973. Dynamics of the Party System: Alignment and Realignment of Political Parties in the United States. Washington DC: The Brookings Institution.

[54] Von Hagen, Jurgen, and Ian Harden. 1996. Budget Process and Commitment to Fiscal Discipline. IMF Working Paper No. 96/78

[55] Wooldridge, Jeffrey. 2002. Econometric Analysis of Cross Section and Panel Data. Boston: MIT Press. 